\title{
Apis mellifera propolis enhances apoptosis and invasion inhibition in head and neck cancer cells
}

\author{
Nattisa Niyomtham ${ }^{1}$, Sittichai Koontongkaew ${ }^{1}$, Boon-ek Yingyongnarongkul ${ }^{2}$, Kusumawadee Utispan ${ }^{\text {Corresp. } 3}$ \\ ${ }^{1}$ Walailak University International College of Dentistry, Walailak University, Bangkok, Thailand \\ 2 Department of Chemistry, Faculty of Science, Ramkhamhaeng University, Bangkok, Thailand \\ 3 Faculty of Dentistry, Thammasat University, Pathum Thani, Thailand \\ Corresponding Author: Kusumawadee Utispan \\ Email address: kusumawadee.utispan@gmail.com
}

Background. Propolis is a resinous product accumulated from several plant sources that possess a wide range of therapeutic properties, including anti-cancer activities. However, the role of honeybee-produced propolis on head and neck squamous carcinoma (HNSCC) is not well understood. The aim of this study was to investigate the effects of Apis mellifera propolis on apoptosis and invasiveness in HNSCC cell lines. Methods. Ethyl acetate extract of propolis (EAEP) was prepared from $A$. mellifera beehives using liquid-liquid extraction. High-performance liquid chromatography coupled with electrospray ionizationtime of flight-mass spectrometry (HPLC-ESI-TOF-MS) was used to determine the flavonoids in EAEP. Isogenic HNSCC cell lines derived from primary (HN30 and HN4) and metastatic site (HN31 and HN12) were used in this study. The cytotoxicity, apoptosis, invasion, and MMP activity of EAEP on HNSCC cells were determined using an MTT assay, flow cytometry, Matrigel invasion assay, and gelatinase zymography, respectively. Results. We found that EAEP exhibited cytotoxic activity and induced apoptosis in the HNSCC cell lines. Furthermore, EAEP significantly decreased HNSCC cell invasion by reducing MMP-2 and MMP-9 activity. Two flavonoids, galangin and apigenin, were identified in EAEP by HPLC-ESI-TOF-MS. The results suggest that EAEP promoted apoptosis and exerts antiinvasion potential by inhibiting MMP-2 and MMP-9 activity in HNSCC cell lines. These inhibitory effects may be mediated by galangin and apigenin. 
1 Apis mellifera propolis enhances apoptosis and invasion inhibition in 2 head and neck cancer cells

3

4

5

Nattisa Niyomtham ${ }^{1}$, Sittichai Koontongkaew ${ }^{1}$, Boon-ek Yingyongnarongkul ${ }^{2}$, Kusumawadee Utispan ${ }^{3}$

${ }^{1}$ Walailak University International College of Dentistry, Walailak University, Bangkok, Thailand.

${ }^{2}$ Department of Chemistry and Center of Excellence for Innovation in Chemistry, Faculty of Science, Ramkhamhaeng University, Bangkok, Thailand.

${ }^{3}$ Faculty of Dentistry, Thammasat University, Pathum Thani, Thailand

Corresponding Author:

Kusumawadee Utispan ${ }^{3}$

Email address: kusumawadee.utispan@gmail.com 


\section{Abstract}

38 Background. Propolis is a resinous product accumulated from several plant sources that

39

40

41

42

43

44

45

46

47

48

49

50

51

52

53

54

55

56

57

58

59

60

61

62

63

64

65

66

67

68

69 possess a wide range of therapeutic properties, including anti-cancer activities. However, the role of honeybee-produced propolis on head and neck squamous carcinoma (HNSCC) is not well understood. The aim of this study was to investigate the effects of Apis mellifera propolis on apoptosis and invasiveness in HNSCC cell lines.

Methods. Ethyl acetate extract of propolis (EAEP) was prepared from A. mellifera beehives using liquid-liquid extraction. High-performance liquid chromatography coupled with electrospray ionization-time of flight-mass spectrometry (HPLC-ESI-TOF-MS) was used to determine the flavonoids in EAEP. Isogenic HNSCC cell lines derived from primary (HN30 and HN4) and metastatic site (HN31 and HN12) were used in this study. The cytotoxicity, apoptosis, invasion, and MMP activity of EAEP on HNSCC cells were determined using an MTT assay, flow cytometry, Matrigel invasion assay, and gelatinase zymography, respectively.

Results. We found that EAEP exhibited cytotoxic activity and induced apoptosis in the HNSCC cell lines. Furthermore, EAEP significantly decreased HNSCC cell invasion by reducing MMP-2 and MMP-9 activity. Two flavonoids, galangin and apigenin, were identified in EAEP by HPLC-ESI-TOF-MS. The results suggest that EAEP promoted apoptosis and exerts anti-invasion potential by inhibiting MMP-2 and MMP-9 activity in HNSCC cell lines. These inhibitory effects may be mediated by galangin and apigenin.

57


70

71

72

73

74

75

76

77

78

79

80

81

82

83

84

85

86

87

88

89

90

91

92

93

94

95

96

97

98

99

\section{Introduction}

Head and neck squamous cell carcinoma (HNSCC) is the seventh most common cancer worldwide and the highest occurring cancer observed in southern Asia.

Currently, the typical HNSCC treatment is surgical removal, combined with chemotherapy and/or radiation therapy (Chow 2020; Schwartz \& Hayes 2020). Similar to other tumors, proliferation, invasion, and metastasis are the critical processes that indicate HNSCC aggressiveness (Chan et al. 2016; Wolf \& Claudio 2014). Evading apoptosis is one way by which cancer cells survive in an extreme microenvironment (Raudenska et al. 2021). HNSCC invasion and metastasis are driven by matrix metalloproteinase (MMP) activity. MMP-2 and MMP-9 are the key enzymes that destroy the basement membrane and degrade the extracellular matrix, leading to tumor invasion (Koontongkaew 2013). Thus, more effective treatments that trigger apoptosis in cancer cells for local and metastatic HNSCC are needed (Khan et al. 2012).

Propolis, or bee glue, is a natural resinous material collected by honey bees from various tree buds to seal cracks in the hive and protect the hive against bacterial and fungal infection (Calegari et al. 2017). Propolis has been used in traditional medicine in many countries. More than 300 chemical compounds have been identified from propolis in different geographic regions (Drescher et al. 2019; Xuan et al. 2016), including flavonoids, terpenes, phenolic acid, cinnamic acid, caffeic acid, and several esters (Funakoshi-Tago et al. 2016; Jaiswal et al. 1997; Kocot et al. 2018). Propolis has a wide range of pharmaceutical properties, including antimicrobial (Al-Ani et al. 2018; Chen et al. 2018), anti-inflammatory, antioxidant (Kocot et al. 2018), anti-angiogenic (Iqbal et al. 2019), and anti-cancer (Badr et al. 2011; Frozza et al. 2017; Sawicka et al. 2012) effects. The crude extracts of propolis have demonstrated cytotoxic activity against various cancer cell lines, such as human prostate cancer cells (DU145 and PC-3) (Li et al. 2007), cervix adenocarcinoma cells (HeLa) (Barbaric et al. 2011), human laryngeal epidermoid carcinoma cells (Hep-2) (Frozza et al. 2017), human colorectal adenocarcinoma cells (HT-29), human breast adenocarcinoma cells (MCF-7), human epithelial colorectal adenocarcinoma cells (Caco-2), and murine melanoma cell lines (B16F1) (Choudhari et al. 2013). 
100

101

102

103

104

105

106

107

108

109

110

111

112

113

114

115

116

117

118

119

120

121

122

123

124

125

126

127

128

129

It has been reported that the biological and pharmacological activities of propolis depend on its chemical composition, geographical zone, plant source, and season (Devequi-Nunes et al. 2018; Omar et al. 2017; Siheri et al. 2016). Propolis extracts from Apis mellifera beehives in Thailand have demonstrated anti-proliferative and cytotoxic activity against cancer cell lines derived from human breast carcinoma (BT474), human hepatocellular carcinoma (Hep-G2), gastric carcinoma (KATO-III), and colon adenocarcinoma (SW620) (Teerasripreecha et al. 2012). Moreover, the propolis extract from Trigona sirindhornae exhibited cytotoxic effects against HNSCC cells (Utispan et al. 2017). However, there are few studies on the effect of Thai $A$. mellifera propolis extract on HNSCC cell lines. Therefore, the aim of this study was to investigate the cytotoxic, apoptotic, and anti-invasive activity of the ethyl acetate extract from Thai $A$. mellifera propolis on primary and metastatic HNSCC cell lines.

\section{Materials and Methods}

\section{Chemicals}

Apigenin, galangin, caffeic acid, ferulic acid, rutin, quercetin, and naringenin were purchased from Sigma-Aldrich (St. Louis, MO, USA). Acetonitrile (HPLC grade) was purchased from RCl Labscan (Bangkok, Thailand). Hexane, ethyl acetate, ethanol, methanol, and formic acid (analytical grade) were purchased from Merck (Darmstadt, Germany).

\section{Ethanol extract of propolis (EEP) preparation}

The propolis sample from the native Thai bee species A. mellifera was obtained in November 2017 in Loei province, northeastern Thailand. The sample was stored in a desiccator and kept in the dark at $4^{\circ} \mathrm{C}$ until processed. Raw propolis $(5.27 \mathrm{~g})$ was cut into small pieces and stirred in $100 \mathrm{ml} 95 \%(\mathrm{v} / \mathrm{v})$ ethanol $(\mathrm{EtOH})$ at $100 \mathrm{rpm}$ at room temperature for $48 \mathrm{~h}$ in the dark. The insoluble portion was separated by filtration through No. 2 Whatman filter paper (Whatman Inc, Piscataway, NJ, USA). To increase the extract yield, this procedure was repeated three times on the same sample. The resulting filtrates were pooled and dried in a rotatory evaporator at $40^{\circ} \mathrm{C}$ and $175 \mathrm{mbar}$ (Rotovapor R-215, 
130 BUCHI Labortechnik, AG, Switzerland). The ethanol extract of propolis (EEP, $4.32 \mathrm{~g}$ ) with 131 a viscous appearance was obtained.

\section{Liquid-liquid partitioning}

EEP was fractioned using liquid-liquid partitioning. The EEP $(4.32 \mathrm{~g})$ was dissolved in $100 \mathrm{ml}$ methanol and then partitioned with hexane $(3 \times 50 \mathrm{ml})$. The combined hexane extract was then rotatory evaporated at $40^{\circ} \mathrm{C}$ and 335 mbar to yield the hexane extract of propolis $(0.98 \mathrm{mg})$. The methanol portion was evaporated at $40^{\circ} \mathrm{C}$ and $337 \mathrm{mbar}$. The methanol extract was dissolved in $100 \mathrm{ml}$ distilled water and underwent liquid-liquid partitioning with ethyl acetate $(3 \times 50 \mathrm{ml})$. After the ethyl acetate was evaporated under reduced pressure on a rotary evaporator, the residual solvent was removed by drying under vacuum (Edwards RV12 rotary vane vacuum pump, Bolton, England) at room temperature for $16 \mathrm{~h}$. The residual ethyl acetate in EAEP was determined by Nuclear Magnetic Resonance (NMR) Spectroscopy. The crude extract was dissolved in DMSO$\mathrm{d}_{6}$ (Sigma-Aldrich, St. Louis, MO, USA) and the ${ }^{1} \mathrm{H}-\mathrm{NMR}$ spectrum was recorded on a Bruker ASCEND 400 FT-NMR spectrometer (Bruker, Faellanden, Switzerland) operating at $400 \mathrm{MHz}$. The chemical shifts are shown as parts per million (ppm). Finally, solid masses were obtained for the ethyl acetate extract (EAEP, $1.92 \mathrm{~g}$ ) and aqueous extract $(0.12 \mathrm{~g})$ after complete solvent evaporation.

Most of the substances found in propolis were obtained in polar organic solvents, including ethanol, methanol, and ethyl acetate (Sambou et al. 2020). Solvents, e.g. ethyl acetate, are used in extraction processes because of its chemical and biological functions, such as its medium polarity (polarity index $=4.3$ ) (Synder 1974). The biphasic action of this solvent enables it to be used to extract both polar and non-polar compounds (Mandal et al. 2015). Ethyl acetate is classified as a class 3 solvent with low toxic potential (Abarca-Vargas et al. 2016; Aru et al. 2019). Furthermore, previous studies demonstrated that the ethyl acetate extracts of many medicinal plants were not cytotoxic to normal cells (El Khalki et al. 2018; Jain et al. 2011; Seklic et al. 2018). Therefore, only EAEP was used in the present study. Before use, the EAEP extract was dissolved in dimethyl sulfoxide (DMSO) and placed in a freezer $\left(-30^{\circ} \mathrm{C}\right)$ until use. 


\section{Cell culture}

162 Two pairs of isogenetic HNSCC cell lines representing primary and metastatic 163 disease from the same patient were first established at Wayne State University by Ensley 164 J. (Cardinali et al. 1995) who collaborated with a researcher at the National Institute of 165 Dental and Craniofacial Research under the supervision of Gutkind S. Gutkind S. 166 provided the cell lines as a gift to Koontongkaew S. The HN30 and HN31 cells were 167 obtained from primary pharynx lesions and lymph node metastases (T3N1M0), 168 respectively. The HN4 and HN12 cells were obtained from primary tongue lesions and 169 lymph node metastases (T4N1M0), respectively. The cells were maintained in Dulbecco's 170 Modified Eagle's Medium (DMEM) (Invitrogen, Carlsbad, CA, USA) supplemented with $17110 \%$ fetal bovine serum, $100 \mathrm{U} / \mathrm{ml}$ penicillin, $100 \mu \mathrm{g} / \mathrm{ml}$ streptomycin (Invitrogen) and an 172 anti-fungal agent. The cells were cultured in a $37^{\circ} \mathrm{C}$ humidified $5 \% \mathrm{CO}_{2}$ atmosphere. The 173 cells were passaged with $0.25 \%$ trypsin-EDTA when reaching $70-80 \%$ confluence.

174

\section{Cell viability-MTT assay}

The cytotoxicity of EAEP on the HNSCC cell lines was investigated using the methyl thiazotetrazolium (MTT) as previously described (Utispan et al. 2020). Briefly, the incubation periods for the MTT assay were 24,48 , or $72 \mathrm{~h}$. However, tumor cells are very heterogenous and their doubling times vary. Therefore, a $24 \mathrm{~h}$ incubation period was enough if the doubling time was $\sim 16-24 \mathrm{~h}$. However, for certain cancer cell lines, a $24 \mathrm{~h}$ incubation period with a given test substance is too short to demonstrate a significant effect on cell viability (Abdul Latif et al. 2019; Alizadeh-Navaei et al. 2016; Guo et al. 2015). Therefore, in the present study, a $72 \mathrm{~h}$ incubation period was used to assess cell toxicity. The HNSCC cells were seeded in 96-well plates at a density of 2,000 cells/well. The cells were treated with serum-free DMEM with $0.1 \%$ DMSO (vehicle control) or EAEP $(0.10-0.40 \mathrm{mg} / \mathrm{ml})$ at $37{ }^{\circ} \mathrm{C}$ for $72 \mathrm{~h}$. After the exposure period, the media was removed, and the cells were washed with phosphate-buffered saline (PBS), and incubated with 0.5 $\mathrm{mg} / \mathrm{ml}$ MTT (Sigma) in culture media for $4 \mathrm{~h}$. The purple formazan crystals of the viable cells were dissolved and measured at $570 \mathrm{~nm}$ by a microplate reader (Tecan, Salzburg, Austria). Cell viability was calculated as a percentage of that of the control (untreated) cells. Each EAEP concentration was independently assayed three times with three 
192 technical replicates. Based on ISO 10993-5, cell viability above $80 \%$ was considered non193 cytotoxic, between 80\%-60\% weak, 60\%-40\% moderate, and below 40\% strong 194 cytotoxicity, respectively (International Organization for Standardization ISO 10993-5 195 2009).

\section{Apoptosis assay}

To verify that the effect of the studied extracts on the growth inhibition of HNSCC cells was related to apoptosis, the apoptosis and necrotic cells were analyzed using 200 annexin-V-fluorescein isothiocyanate (FITC) and propidium iodide (PI) staining. The cells 201 were seeded in 6-well plates and allowed to attach for $24 \mathrm{~h}$. The cells were then treated 202 with EAEP at the weak cytotoxic dose (cell viability of $60 \%-80 \%$ ) for $24 \mathrm{~h}$. The HN12, 203 $\mathrm{HN} 30$, and HN31 cells were treated with $0.2 \mathrm{mg} / \mathrm{ml}$ EAEP, whereas the HN4 cells were treated with $0.3 \mathrm{mg} / \mathrm{ml}$ EAEP. The cells were washed twice with PBS and detached by 205 $0.25 \%$ trypsin, washed with PBS and resuspended in ice cold binding buffer. The 206 apoptotic cells were assessed using the BD Annexin V FITC Assay (BD Biosciences, San 207 Jose, CA, USA). Ten thousand events were analyzed in a flow cytometer (Cytoflex®, 208 Beckman Coulter, Indianapolis, IN, USA). The percent viable, apoptotic and necrotic cells 209 were determined by CytExpert Software (Beckman Coulter).

\section{Invasion assay}

The modified Boyden chemotaxis chamber (Neuro Probe, Gaithersburg, MD, USA) assay used for the cell invasion analysis is based on a chamber with two medium filled compartments as previously described (Albini et al. 1987). Matrigel, a reconstituted basement membrane gel (BD Bioscience, San Jose, CA)) was applied to a polycarbonate membrane filter (13 mm-diameter, $8.0 \mu \mathrm{m}$ pore size, Whatman). The filter was placed above the lower chamber that contained serum-free DMEM with $0.1 \%$ bovine serum albumin (BSA, Sigma). HN4, HN12, HN30, or HN31 cells $\left(1 \times 10^{5}\right.$ cells) were resuspended in $0.1 \mathrm{mg} / \mathrm{ml}$ EAEP diluted in DMEM containing $0.1 \%$ BSA and seeded into the upper well of the chamber. The cells were incubated for $5 \mathrm{~h}$, then the filters were fixed and stained with crystal violet for $10 \mathrm{~min}$. The invaded cells were counted by two investigators using 
222 a microscope at 400x magnification. The invaded cell counts were averaged from five 223 randomly selected fields.

224

225

226

227

228

229

230

231

232

233

234

235

236

237

238

239

240

241

242

243

244

245

246

247

248

249

250

251

252

\section{Conditioned medium preparation and zymography}

HN4, HN12, HN30, or HN31 cells ( $1 \times 10^{6}$ cells) were cultured in 6-well plates and incubated at $37^{\circ} \mathrm{C}$ for $24 \mathrm{~h}$. After incubation, the wells were washed with PBS and treated with $0.1 \mathrm{mg} / \mathrm{ml}$ EAEP diluted in DMEM containing $0.1 \% \mathrm{BSA}$ for $48 \mathrm{~h}$. Cells cultured in DMEM containing $0.1 \%$ BSA were used as control. The conditioned medium (CM) was collected as previously described in Utispan et al., 2020 (Utispan et al. 2020).

The MMP-2 and MMP-9 activity in the CM were measured using gelatin zymography as previously described (Koontongkaew et al. 2009). The clear bands in the gel were identified as degrading activity of MMPs. Images of the stained gels and the gelatinolytic band quantification were processed using the G:BOX gel documentation system (Syngene, Frederick, MD, USA) and Gene Tools software (Syngene), respectively. Three independent experiments were performed.

\section{HPLC-ESI-TOF-MS analysis of EAEP}

High-performance liquid chromatography coupled with electrospray ionization-time of flight-mass spectrometry (HPLC-ESI-TOF-MS) was used to investigate selected phenolic acids and flavonoids in EAEP. EAEP was prepared at $5 \mathrm{mg} / \mathrm{ml}$ in ethanol and filtered through a $0.45 \mu \mathrm{m}$ membrane filter. Although a large number of natural compounds have been reported in propolis, we focused on specific substances in propolis that exhibit anti-cancer activity (Anjum et al. 2019), Thus, we investigated the presence of apigenin, galangin, caffeic acid, ferulic acid, rutin, quercetin, and naringenin in EAEP. To identify the compounds, seven standard polyphenolic compounds (apigenin, galangin, caffeic acid, ferulic acid, rutin, quercetin and naringenin) were dissolved in methanol (10 ppm). The analyses were conducted in an UltiMate $₫ 3000$ system (Thermo Fisher Scientific, DionexSoftron $\mathrm{GmbH}$, Dornierstr. 4, Germany) with a reverse phase column (C18 analysis column, $2.1 \mathrm{~mm} \times 150 \mathrm{~mm}$ and $3 \mu \mathrm{m}$ particle size, Thermo Fisher Scientific, Sunnyvale, CA, USA) at $40^{\circ} \mathrm{C}$. The injection volume for all samples was $5 \mu \mathrm{l}$. The mobile phase consisted of solvent (A) $0.1 \%(\mathrm{v} / \mathrm{v})$ formic acid in water, and solvent (B) acetonitrile, 
253 which had been degassed and filtered. The gradient program for the HPLC was: $0-1$ min, $2545 \%$ B; $1-40$ min $5-55 \%$ B; $41-50$ min $55-95 \%$ B; $50.1-55$ min $5 \%$ B, and the flow rate was $2550.3 \mathrm{ml} / \mathrm{min}$.

256

257

258

259

260

261

262

263

264

265

266

267

268

269

270

271

272

273

274

275

276

277

278

279

280

281

282

The separated components from the HPLC system were subjected to mass to charge ratio $(\mathrm{m} / \mathrm{z})$ analysis using an ESI-TOF-MS system. ESI-TOF-MS was carried out using a time of flight mass spectrometer (micrOTOF-Q-II, Bruker Daltonik, Bremen, Germany). An electrostray ion source (ESI) was used in negative ion mode (ESI-) with the following settings: capillary voltage $3 \mathrm{kV}$, nebulizer gas pressure $2.0 \mathrm{bar}$, dry gas temperature $200^{\circ} \mathrm{C}$, and dry gas flow rate $8.0 \mathrm{~L} / \mathrm{min}$. Spectra were collected from $\mathrm{m} / \mathrm{z} 50$ - 1000 Da. Bruker Compass Data Analysis 4.0 software (Bruker Daltonik) was used for recording and processing the data. The phenolic and flavonoid content in EAEP was determined by interpolation with a calibration curve constructed using the standard solutions of selected polyphenols. The determination was performed 3 times.

\section{Statistical analysis}

Data analyses were performed using GraphPad Prism 7.04 software (GraphPad Software, La Jolla, CA, USA). All results are expressed as means and standard error of the mean (SEM) values from three independent experiments. $P \leq 0.05$ was considered statistically significant using one-way ANOVA followed by Dunnett's multiple comparison.

\section{Results}

\section{Cytotoxic assessment of EAEP on HNSCC cell lines}

The cytotoxic effect of EAEP was evaluated using an MTT assay. The EAEP $(0.2$ $\mathrm{mg} / \mathrm{ml}$ ) significantly decreased the HN30 and HN12 cell viability compared with the control in a dose-dependent manner, whereas the HN4 and HN31 cells demonstrated significantly reduced cell viability at 0.25 and $0.1 \mathrm{mg} / \mathrm{ml}$ EAEP, respectively in a dosedependent manner (Fig. 1A-D). The $\mathrm{IC}_{50}$ value of EAEP for the HN30, HN31, HN4, and $\mathrm{HN} 12$ cells were $0.19,0.16,0.31$, and $0.14 \mathrm{mg} / \mathrm{ml}$, respectively. However, according to ISO 10993-5, the non-cytotoxic dose (cell viability above 80\%) for the HN12, HN30, and HN31 cells was $0.1 \mathrm{mg} / \mathrm{ml}$ EAEP, whereas $0.2 \mathrm{mg} / \mathrm{ml}$ EAEP was not toxic to the HN4 
283 cells. Therefore, the non-cytotoxic concentration at $0.1 \mathrm{mg} / \mathrm{ml}$ was selected to treat the 284 HNSCC cell lines and evaluate their invasion and MMP activity in the subsequent 285 286 287 288 289 290 291

\section{Apoptotic effects of EAEP} experiments. The weak cytotoxic dose (cell viability of $60-80 \%$ ) was used for the apoptosis assay.

apoptosis was an underlying mechanism. Flow cytometry was used to quantify the apoptotic, alive, and necrotic cells. The HN12, HN30, and HN31 cells were exposed to $0.2 \mathrm{mg} / \mathrm{ml}$ EAEP. The HN4 cells were treated with $0.3 \mathrm{mg} / \mathrm{ml}$ EAEP. We found that EAEP induced $42.42 \%, 44.01 \%, 43.28 \%$, and $13.08 \%$ apoptosis in the HN30, HN31, HN4, and HN12, cells respectively (Fig. 2).

\section{EAEP decreased HNSCC invasion}

HNSCC cell invasion using a Boyden chamber system was used as a functional assay. We found that HNSCC invasion was down-regulated after EAEP treatment for 5 h. EAEP at the non-toxic concentration $(0.1 \mathrm{mg} / \mathrm{ml})$ decreased the invasiveness of the HN30, HN31, HN4, and HN12 cells by approximately $51 \%, 67 \%, 37 \%$, and $56 \%$, respectively, compared with control (Figs. 3A and 3B).

\section{EAEP reduced the MMP activity of HNSCC cells}

To determine whether MMPs were down-regulated in EAEP-treated HNSCC cells, the cell culture medium of the HNSCC cells was assayed for MMP-2 and MMP-9 activity after treatment with EAEP for $48 \mathrm{~h}$. The zymographic data demonstrated that EAEP inhibited the MMP-2 and MMP-9 activity of the HN30, HN31, HN4, and HN12 cells (Fig. 4A). Quantitative analysis of the MMP activity revealed that at the non-toxic concentration $(0.1 \mathrm{mg} / \mathrm{ml})$, EAEP significantly reduced the MMP-2 activity of the HN30 and HN31 cells by $64 \%$ and $27 \%$, respectively (Fig. 4B). However, the MMP-2 activity in the EAEPtreated HN4 and HN12 and control cells was not significantly different. In contrast, 0.1 
$312 \mathrm{mg} / \mathrm{ml}$ EAEP significantly decreased MMP-9 activity in the HN30, HN31, HN4, and HN12 313 cells to approximately $51 \%, 32 \%, 18 \%$, and $21 \%$, respectively.

314

315 HPLC-ESI-TOF-MS analysis of EAEP

316

HPLC-ESI-TOF-MS was used to analyze the profiles of the phenolics and

317 flavonoids ofin EAEP. Commercially available polyphenolic compounds were used as 318 standards in this determination. Baseline calibration of the HPLC system was performed 319 using the sample solvent (Fig. 5A). Although very minor peaks were present, only two 320 compounds were detected in a measurable quantity. The EAEP chromatograms 321 demonstrated peaks 1 and 2 with retention times that corresponded to those of apigenin 322 (24.7 $\mathrm{min}$ ) and galangin (32.9 min), respectively (Figs. 5B and 5C). The HPLC-ESI-TOF323 MS parameters were optimized and used to profile EAEP. The selected 2 compounds in 324 EAEP were putatively identified by comparison to the database (Table 1). The results 325 revealed that compound 1 and 2 were apigenin and galangin, respectively. The amount 326 327 328 and chemical structures of apigenin and galangin are shown in Figure 6. The concentration of these phenolic compounds in EAEP was estimated by interpolation with a calibration curve constructed with standard solutions of apigenin and galangin. The quantitative determination revealed that the amount (mean \pm SD) of apigenin and galangin in the EAEP was $149.0 \pm 7.07 \mu \mathrm{g} / \mathrm{g}$ and $628.66 \pm 16.42 \mu \mathrm{g} / \mathrm{g}$, respectively.

\section{Detection of residual solvent in EAEP}

The final product extract should not contain any residual solvent to ensure that the biological activities observed were not due to ethyl acetate in the test fraction. The residual solvents were evaporated under reduced pressure on a rotatory evaporator, followed by residual solvent removal in a vacuum dryer for $16 \mathrm{~h}$. Further, ${ }^{1} \mathrm{H}-\mathrm{NMR}$ analysis of the ethyl acetate confirmed the absence of residual ethyl acetate in the EAEP. Three sets of protons were responsible for the three signals in the ${ }^{1} \mathrm{H}-\mathrm{NMR}$ spectra of ethyl acetate (Fig. 7A). The two $\mathrm{H}_{\mathrm{b}}$ protons in ethyl acetate split the $\mathrm{H}_{\mathrm{c}}$ signal into a triplet at approximately $\delta 1.70 \mathrm{ppm}$, and the three $\mathrm{H}_{\mathrm{c}}$ protons split the $\mathrm{Hb}$ signal into a quartet at approximately $\delta 4.02 \mathrm{ppm}$. There was an unsplit single peak at approximately $\delta 1.98 \mathrm{ppm}$ 
342 that corresponds to the acetyl $\left(\mathrm{H}_{\mathrm{a}}\right)$ protons. The ${ }^{1} \mathrm{H}-\mathrm{NMR}$ spectra were consistent with a 343 previous report (Fulmer et al. 2010). The ${ }^{1} \mathrm{H}-\mathrm{NMR}$ spectrum of EAEP did not exhibit 344 signals identifying ethyl acetate (Fig. 7B). Therefore, the ${ }^{1} \mathrm{H}-\mathrm{NMR}$ spectra indicated that 345 the EAEP extract was not contaminated with ethyl acetate. This confirms that the 346 bioactive compounds in EAEP were responsible for the cytotoxicity, apoptosis, cell 347 invasion, and MMP activity of HNSCC cell lines in our studies.

\section{Discussion}

The main objective of the present study was to evaluate the anti-cancer effect and establish the underlying mechanisms of Thai propolis on HNSCC cells. This study investigated, for the first time, the anticancer effect of the ethyl acetate extract of propolis (EAEP) from Thai A. mellifera on primary and metastatic HNSCC cell lines. We found that EAEP demonstrated a dose-dependent cytotoxic effect and caused apoptosis in the HN30, HN31, HN4, and HN12 cell lines. Our findings agree with previous studies demonstrating the anti-cancer effects of propolis obtained from many countries. Brazilian propolis extract inhibits cell growth and induces apoptotic mechanisms in human prostate carcinoma (DU145 and PC-3 cells) (Li et al. 2007). Similarly, a propolis extract from Turkey inhibited cell proliferation and induced apoptosis and cell cycle arrest in breast cancer (MCF7), lung cancer (A549) and gastric cancer (HGC27) (Aru et al. 2019; Misir et al. 2020).

We analyzed standards of apigenin, galangin, caffeic acid, ferulic acid, rutin, 363 quercetin and naringenin, however; only apigenin and galantine were observed in our propolis samples. This finding demonstrated that propolis extracts differ qualitatively and quantitatively regarding phenolic acids and flavonoids (Anjum et al. 2019). Apigenin (Swanson et al. 2014; Yan et al. 2017; Zhu et al. 2016) and galangin (Seyhan et al. 2019; Yang et al. 2018; Zhu et al. 2014) have demonstrated anticancer activity against various cancer cell lines and they might be involved in the cytotoxic effect on HNSCC cell lines. These results suggest that the cytotoxic activities of phenolic compounds depends on their chemical structure, especially the total number of hydroxyl groups in their molecules

371 (Czyzewska et al. 2016). Here, we demonstrated the inhibition of HNSCC cell proliferation 372 by propolis extracts could occur, at least partially, through apoptosis. Apigenin and 373 galangin may play an important role in the EAEP cytotoxic effect on HNSCC cell lines. 
374 The mechanism by which EAEP caused apoptosis in HNSCC cells is unclear. These 375 phenolic compounds may induce apoptosis in HNSCC cells by decreasing the expression 376 of antiapoptotic proteins and increasing the expression of proapoptotic proteins (Zhu et

377

378

379

380

381

382

383

384

385

386

387

388

389

390

391

392

393

394

395

396

397

398

399

400

401

402

403

404

405

406

407

408

409 al. 2014). EAEP might modulate the caspase-3 and AKT signaling pathways (Wang \& Tang 2017). However, the synergistic effects of polyphenols in the propolis extract might be responsible for their cytotoxicity (Czyzewska et al. 2016) .

Invasion and migration are considered important hallmarks of malignant tumors. MMP-2 and MMP-9 are enzymes that play an important role in basement membrane degradation, which is the first step in the invasion and metastasis of cancer cells (Koontongkaew, 2013). In the present study, we investigated the effects of EAEP on cell invasion by focusing on the activity of MMP-2 and MMP-9 in HNSCC cell lines. Notably, EAEP significantly decreased the invasion of stage III, HN30 and HN31, cells by inhibiting MMP-2 and MMP-9 activity. However, the extract reduced invasion of stage IV, HN4 and HN12, cells by attenuating only MMP-9 activity. Previous studies found that apigenin inhibited the invasion and migration of human metastatic cancer cell lines by reducing MMP-9 expression by suppressing the p38 MAPK signaling pathways (Noh et al. 2010). Moreover, galangin reduces MMP-9 expression and cell migration in human neuroblastoma cell lines (Yang et al. 2018) and human fibrosarcoma cells (Choi et al. 2015). Based on these and our findings, we hypothesize that apigenin and galangin in EAEP may be a key factor in inhibiting invasive HNSCC cells.

Previous studies have reported the cytotoxic and anti-invasiveness concentrations of apigenin and galangin in the range $0.01-0.1$ and $5-30 \mu \mathrm{g} / \mathrm{ml}$, respectively (Seyhan et al. 2019; Swanson et al. 2014). In the present study we obtained 1,920 mg EAEP and found approximately 286.08 and $1,207 \mu \mathrm{g}$ apigenin and galangin, respectively, in the extract. We estimated that the effective dose of EAEP contains maximum concentrations of 0.045 and $0.188 \mu \mathrm{g} / \mathrm{ml}$ of apigenin and galangin respectively. These results imply that apigenin and galangin are at least two candidate compounds that exhibit anticancer effects on HNSCC cells. Based on the results of the present study, other compounds in EAEP should be identified and their synergistic effect investigated.

One limitation of our study is that we did not compare the biological activities of EAEP between HNSCC cells and normal cells. Therefore, it is difficult to specify that the EAEP activities are specific to cancer cells. To clarify these observations, further studies are needed to investigate the anticancer activities in counterpart normal cells. Additional in vivo studies should be undertaken to determine the efficacy of EAEP and its related compounds in inhibiting tumor progression. 
410 Conclusions

411

412

413

414

415

416

417

418

419

420

421

422

423

424

425

426

427

428

429

430

431

432

433

434

435

436

437

438

439

440

441

442

443

444

445

446

447

In conclusion, the present study revealed that EAEP from Thai $A$. mellifera has a dose-dependent cytotoxic effect and induces apoptosis of HNSCC. The EAEP inhibited the invasion of primary and metastatic HNSCC cells by inhibiting MMP-2 and MMP-9 expression. Apigenin and galangin were identified in the EAEP. These two flavonoids may contribute to the anti-cancer activities of EAEP. Therefore, the EAEP has the potential to be a powerful candidate in developing preventive agents for cancer metastasis and this beneficial effect may expand future research on the anticancer properties of EAEP in vitro and in vivo.

\section{Acknowledgements}

The authors thank Professor Silvio Gutkind (Moores Cancer Center, Department of Pharmacology, UCSD, CA, USA) for the HNSCC cell lines used in our study. We thank Christian Estacio for his assistance in editing the English of this manuscript.

\section{References}

Abarca-Vargas R, Pena Malacara CF, and Petricevich VL. 2016. Characterization of Chemical Compounds with Antioxidant and Cytotoxic Activities in Bougainvillea $x$ buttiana Holttum and Standl, (var. Rose) Extracts. Antioxidants (Basel) 5. 10.3390/antiox5040045

Abdul Latif M, Ibrahim FW, Arshad SA, Chua KH, Jufri NF, and Hamid A. 2019. Cytotoxicity, Proliferation and Migration Rate Assessments of Human Dermal Fibroblast Adult Cells using Zingiber zerumbet Extract. Sains Malays 48:121-127. 10.17576/jsm-2019-4801-14

Al-Ani I, Zimmermann S, Reichling J, and Wink M. 2018. Antimicrobial Activities of European Propolis Collected from Various Geographic Origins Alone and in Combination with Antibiotics. Medicines (Basel) 5. 10.3390/medicines5010002

Albini A, Iwamoto Y, Kleinman HK, Martin GR, Aaronson SA, Kozlowski JM, and McEwan RN. 1987. A rapid in vitro assay for quantitating the invasive potential of tumor cells. Cancer Res 47:3239-3245.

Alizadeh-Navaei R, Rafiei A, Abedian-Kenari S, Asgarian-Omran H, Valadan R, and Hedayatizadeh-Omran A. 2016. Effect of First Line Gastric Cancer Chemotherapy Regime on the AGS Cell Line - MTT Assay Results. Asian Pac J Cancer Prev 17:131-133. 10.7314/apjcp.2016.17.1.131

Anjum SI, Ullah A, Khan KA, Attaullah M, Khan H, Ali H, Bashir MA, Tahir M, Ansari MJ, Ghramh HA, Adgaba N, and Dash CK. 2019. Composition and functional properties of propolis (bee glue): A review. Saudi J Biol Sci 26:1695-1703. 10.1016/j.sjbs.2018.08.013 
448

449

450

451

452

453

454

455

456

457

458

459

460

461

462

463

464

465

466

467

468

469

470

471

472

473

474

475

476

477

478

479

480

481

482

483

484

485

486

487

488

489

490

491

492

Aru B, Guzelmeric E, Akgul A, Demirel GY, and Kirmizibekmez H. 2019. Antiproliferative Activity of Chemically Characterized Propolis from Turkey and Its Mechanisms of Action. Chem Biodivers 16:e1900189. 10.1002/cbdv.201900189

Badr MO, Edrees NM, Abdallah AA, El-Deen NA, Neamat-Allah AN, and Ismail HT. 2011. Anti-tumour effects of Egyptian propolis on Ehrlich ascites carcinoma. Vet Ital 47:341-350.

Barbaric M, Miskovic K, Bojic M, Loncar MB, Smolcic-Bubalo A, Debeljak Z, and MedicSaric M. 2011. Chemical composition of the ethanolic propolis extracts and its effect on HeLa cells. J Ethnopharmacol 135:772-778. 10.1016/j.jep.2011.04.015

Calegari MA, Prasniewski A, Silva CD, Sado RY, Maia FMC, Tonial LMS, and Oldoni TLC. 2017. Propolis from Southwest of Parana produced by selected bees: Influence of seasonality and food supplementation on antioxidant activity and phenolic profile. An Acad Bras Cienc 89:45-55. 10.1590/0001-3765201620160499

Cardinali M, Pietraszkiewicz H, Ensley JF, and Robbins KC. 1995. Tyrosine phosphorylation as a marker for aberrantly regulated growth-promoting pathways in cell lines derived from head and neck malignancies. Int $J$ Cancer 61:98-103. 10.1002/ijc.2910610117

Chan CY, Lien CH, Lee MF, and Huang CY. 2016. Quercetin suppresses cellular migration and invasion in human head and neck squamous cell carcinoma (HNSCC). Biomedicine (Taipei) 6:15. 10.7603/s40681-016-0015-3

Chen YW, Ye SR, Ting C, and Yu YH. 2018. Antibacterial activity of propolins from Taiwanese green propolis. J Food Drug Anal 26:761-768. 10.1016/j.jfda.2017.10.002

Choi YJ, Lee YH, and Lee ST. 2015. Galangin and kaempferol suppress phorbol-12myristate-13-acetate-induced matrix metalloproteinase-9 expression in human fibrosarcoma HT-1080 cells. Mol Cells 38:151-155. 10.14348/molcells.2015.2229

Choudhari MK, Haghniaz R, Rajwade JM, and Paknikar KM. 2013. Anticancer activity of Indian stingless bee propolis: an in vitro study. Evid Based Complement Alternat Med 2013:928280. 10.1155/2013/928280

Chow LQM. 2020. Head and Neck Cancer. $N$ Engl J Med 382:60-72. 10.1056/NEJMra1715715

Czyzewska U, Siemionow K, Zareba I, and Miltyk W. 2016. Proapoptotic Activity of Propolis and Their Components on Human Tongue Squamous Cell Carcinoma Cell Line (CAL-27). PLoS One 11:e0157091. 10.1371/journal.pone.0157091

Devequi-Nunes D, Machado BAS, Barreto GA, Reboucas Silva J, da Silva DF, da Rocha JLC, Brandao HN, Borges VM, and Umsza-Guez MA. 2018. Chemical characterization and biological activity of six different extracts of propolis through conventional methods and supercritical extraction. PLoS One 13:e0207676. 10.1371/journal.pone.0207676

Drescher N, Klein AM, Schmitt T, and Leonhardt SD. 2019. A clue on bee glue: New insight into the sources and factors driving resin intake in honeybees (Apis mellifera). PLoS One 14:e0210594. 10.1371/journal.pone.0210594

El Khalki L, Tilaoui M, Jaafari A, Ait Mouse H, and Zyad A. 2018. Studies on the Dual Cytotoxicity and Antioxidant Properties of Berberis vulgaris Extracts and Its Main Constituent Berberine. Adv Pharmacol Sci 2018:3018498. 10.1155/2018/3018498

Peer) reviewing PDF | (2021:05:61422:1:1:NEW 5 Aug 2021) 
493 Frozza C, Santos DA, Rufatto LC, Minetto L, Scariot FJ, Echeverrigaray S, Pich CT, $494 \quad$ Moura S, Padilha FF, Borsuk S, Savegnago L, Collares T, Seixas FK, Dellagostin

lqbal M, Fan TP, Watson D, Alenezi S, Saleh K, and Sahlan M. 2019. Preliminary studies: the potential anti-angiogenic activities of two Sulawesi Island (Indonesia) propolis and their chemical characterization. Heliyon 5:e01978. 10.1016/j.heliyon.2019.e01978

Jain D, Pathak N, Khan S, Raghuram GV, Bhargava A, Samarth R, and Mishra PK. 2011. Evaluation of cytotoxicity and anticarcinogenic potential of Mentha leaf extracts. Int J Toxicol 30:225-236. 10.1177/1091581810390527

Jaiswal AK, Venugopal R, Mucha J, Carothers AM, and Grunberger D. 1997. Caffeic acid phenethyl ester stimulates human antioxidant response element-mediated expression of the $\mathrm{NAD}(\mathrm{P}) \mathrm{H}$ :quinone oxidoreductase (NQO1) gene. Cancer Res 57:440-446.

Khan Z, Tiwari RP, Khan N, Prasad GB, and Bisen PS. 2012. Induction of apoptosis and sensitization of head and neck squamous carcinoma cells to cisplatin by targeting survivin gene expression. Curr Gene Ther 12:444-453. 10.2174/156652312803519805

Kocot J, Kielczykowska M, Luchowska-Kocot D, Kurzepa J, and Musik I. 2018. Antioxidant Potential of Propolis, Bee Pollen, and Royal Jelly: Possible Medical Application. Oxid Med Cell Longev 2018:7074209. 10.1155/2018/7074209

Koontongkaew S. 2013. The tumor microenvironment contribution to development, growth, invasion and metastasis of head and neck squamous cell carcinomas. $J$ Cancer 4:66-83. 10.7150/jca.5112

Koontongkaew S, Amornphimoltham P, and Yapong B. 2009. Tumor-stroma interactions influence cytokine expression and matrix metalloproteinase activities in paired primary and metastatic head and neck cancer cells. Cell Biol Int 33:165-173. 10.1016/j.cellbi.2008.10.009

Li H, Kapur A, Yang JX, Srivastava S, McLeod DG, Paredes-Guzman JF, Daugsch A, Park YK, and Rhim JS. 2007. Antiproliferation of human prostate cancer cells by 
539

540

541

542

543

544

545

546

547

548

549

550

551

552

553

554

555

556

557

558

559

560

561

562

563

564

565

566

567

568

569

570

571

572

573

574

575

576

577

578

579

580

581

582

583

584 ethanolic extracts of Brazilian propolis and its botanical origin. Int J Oncol 31:601606.

Mandal SC, Mandal V, and Das AK. 2015. Essentials of botanical extraction:Principles and application SanDiego, CA: Academic Press.

Misir S, Aliyazicioglu Y, Demir S, Turan I, and Hepokur C. 2020. Effect of Turkish Propolis on miRNA Expression, Cell Cycle, and Apoptosis in Human Breast Cancer (MCF7) Cells. Nutr Cancer 72:133-145. 10.1080/01635581.2019.1616100

Noh HJ, Sung EG, Kim JY, Lee TJ, and Song IH. 2010. Suppression of phorbol-12myristate-13-acetate-induced tumor cell invasion by apigenin via the inhibition of p38 mitogen-activated protein kinase-dependent matrix metalloproteinase-9 expression. Oncol Rep 24:277-283. 10.3892/or_00000857

Omar R, Igoli JO, Zhang T, Gray AI, Ebiloma GU, Clements CJ, Fearnley J, Edrada Ebel R, Paget T, de Koning HP, and Watson DG. 2017. The Chemical Characterization of Nigerian Propolis samples and Their Activity Against Trypanosoma brucei. Sci Rep 7:923. 10.1038/s41598-017-01038-2

Raudenska M, Balvan J, and Masarik M. 2021. Cell death in head and neck cancer pathogenesis and treatment. Cell Death Dis 12:192. 10.1038/s41419-021-034745

Sambou M, Jean-Francois J, Ndongou Moutombi FJ, Doiron JA, Hebert MPA, Joy AP, Mai-Thi NN, Barnett DA, Surette ME, Boudreau LH, and Touaibia M. 2020. Extraction, Antioxidant Capacity, 5-Lipoxygenase Inhibition, and Phytochemical Composition of Propolis from Eastern Canada. Molecules 25. 10.3390/molecules25102397

Sawicka D, Car H, Borawska MH, and Niklinski J. 2012. The anticancer activity of propolis. Folia Histochem Cytobiol 50:25-37.

Schwartz DL, and Hayes DN. 2020. The Evolving Role of Radiotherapy for Head and Neck Cancer. Hematol Oncol Clin North Am 34:91-108. 10.1016/j.hoc.2019.08.019

Seklic DS, Obradovic AD, Stankovic MS, Zivanovic MN, Mitrovic TL, Stamenkovic SM, and Markovic SD. 2018. Proapoptotic and Antimigratory Effects of Pseudevernia furfuracea and Platismatia glauca on Colon Cancer Cell Lines. Food Technol Biotechnol 56:421-430. 10.17113/ftb.56.03.18.5727

Seyhan MF, Yilmaz E, Timirci-Kahraman O, Saygili N, Kisakesen HI, Gazioglu S, Goren AC, Eronat AP, Begum Ceviz A, Ozturk T, Yilmaz-Aydogan H, and Ozturk O. 2019. Different propolis samples, phenolic content, and breast cancer cell lines: Variable cytotoxicity ranging from ineffective to potent. IUBMB Life 71:619-631. 10.1002/iub.1996

Siheri W, Zhang T, Ebiloma GU, Biddau M, Woods N, Hussain MY, Clements CJ, Fearnley J, Ebel RE, Paget T, Muller S, Carter KC, Ferro VA, De Koning HP, and Watson DG. 2016. Chemical and Antimicrobial Profiling of Propolis from Different Regions within Libya. PLoS One 11:e0155355. 10.1371/journal.pone.0155355

Swanson HI, Choi EY, Helton WB, Gairola CG, and Valentino J. 2014. Impact of apigenin and kaempferol on human head and neck squamous cell carcinoma. Oral Surg Oral Med Oral Pathol Oral Radiol 117:214-220. 10.1016/j.oooo.2013.10.012

Synder L. 1974. Classification of the solvent properties of common liquids. J Chromatogr 92:223-230. 
585 Teerasripreecha D, Phuwapraisirisan P, Puthong S, Kimura K, Okuyama M, Mori H,

586

587

588

589

590

591

592

593

594

595

596

597

598

599

600

601

602

603

604

605

606

607

608

609

610

611

612

613

614

615

616

617

618

619

620

621

622

623

624

625

626
Kimura A, and Chanchao C. 2012. In vitro antiproliferative/cytotoxic activity on cancer cell lines of a cardanol and a cardol enriched from Thai Apis mellifera propolis. BMC Complement Altern Med 12:27. 10.1186/1472-6882-12-27

Utispan K, Chitkul B, and Koontongkaew S. 2017. Cytotoxic Activity of Propolis Extracts from the Stingless Bee Trigona Sirindhornae Against Primary and Metastatic Head and Neck Cancer Cell Lines. Asian Pac J Cancer Prev 18:1051-1055. 10.22034/APJCP.2017.18.4.1051

Utispan K, Niyomtham N, Yingyongnarongkul BE, and Koontongkaew S. 2020. Ethanolic Extract of Ocimum sanctum Leaves Reduced Invasion and Matrix Metalloproteinase Activity of Head and Neck Cancer Cell Lines. Asian Pac J Cancer Prev 21:363-370. 10.31557/APJCP.2020.21.2.363

Wang HX, and Tang C. 2017. Galangin suppresses human laryngeal carcinoma via modulation of caspase-3 and AKT signaling pathways. Oncol Rep 38:703-714. 10.3892/or.2017.5767

Wolf MA, and Claudio PP. 2014. Benzyl isothiocyanate inhibits HNSCC cell migration and invasion, and sensitizes HNSCC cells to cisplatin. Nutr Cancer 66:285-294. 10.1080/01635581.2014.868912

Xuan H, Wang Y, Li A, Fu C, Wang Y, and Peng W. 2016. Bioactive Components of Chinese Propolis Water Extract on Antitumor Activity and Quality Control. Evid Based Complement Alternat Med 2016:9641965. 10.1155/2016/9641965

Yan X, Qi M, Li P, Zhan Y, and Shao H. 2017. Apigenin in cancer therapy: anti-cancer effects and mechanisms of action. Cell Biosci 7:50. 10.1186/s13578-017-0179-x

Yang CC, Lin CC, Hsiao LD, and Yang CM. 2018. Galangin Inhibits Thrombin-Induced MMP-9 Expression in SK-N-SH Cells via Protein Kinase-Dependent NF-kappaB Phosphorylation. Int J Mol Sci 19. 10.3390/ijms19124084

Zhu H, Jin H, Pi J, Bai H, Yang F, Wu C, Jiang J, and Cai J. 2016. Apigenin induced apoptosis in esophageal carcinoma cells by destruction membrane structures. Scanning 38:322-328. 10.1002/sca.21273

Zhu L, Luo Q, Bi J, Ding J, Ge S, and Chen F. 2014. Galangin inhibits growth of human head and neck squamous carcinoma cells in vitro and in vivo. Chem Biol Interact 224:149-156. 10.1016/j.cbi.2014.10.027 
627

628 Figures and Legends

629 Figure 1 Cytotoxic evaluation of EAEP on HNSCC cells measured by MTT assay.

630 The EAEP at various concentrations were used to treat (A) HN30, (B) HN31, (C) HN4, 631 and (D) HN12 cells for $72 \mathrm{~h}$. Bars represent means \pm SEM of three independent 632 experiments $(\mathrm{n}=3)$. ${ }^{*} P<0.05$ compared with the control.

633

634 Figure 2 Effect of EAEP on HNSCC cells, after treatment for $24 \mathrm{~h}$, evaluated by flow 635 cytometry. (A) Dot plots of apoptosis assay with Annexin V-FITC (X-axis)/ 7-AAD-PE (Y636 axis). (B) Percentage of apoptotic HN30, HN31, HN4, and HN12 cells treated with 0.2, $6370.2,0.3$, and $0.2 \mathrm{mg} / \mathrm{ml}$ EAEP, respectively for $24 \mathrm{~h}$. Bars represent means $\pm S E M$ of three 638 independent experiments $(n=3) .{ }^{*} P<0.05$ compared with the control.

639

640 Figure 3 EAEP decreased HNSCC cell invasion. A non-cytotoxic dose of EAEP was 641 used to treat HN30, HN31, HN4, and HN12 cells. (A) Representative images of cells that 642 invaded onto the underside of polycarbonate filters coated with Matrigel membrane from 643 Boyden chemoinvasion assays at 400× magnification using a light microscope. (B) The 644 number of cells of each field was counted using a microscope at 400× magnification. 645 Values are the mean \pm SEM of three independent experiments $(n=3)$ of. ${ }^{*}<0.05$ 646 compared with the control.

647

Figure 4 EAEP reduced MMP activities. EAEP $(0.1 \mathrm{mg} / \mathrm{ml})$ was used to treat the cancer 649 cells for $48 \mathrm{~h}$ and MMP activity in the conditioned media of (A) HN30 and HN31, and (B) 650 HN4 and HN12 cells were detected using zymography. GeneTools software was used to 651 quantify gelatinolytic bands of (C) MMP-2 and (D) MMP-9 activity. Bars represent means \pm SEM of three independent experiments $(n=3)$. ${ }^{*} P<0.05$ compared with the 653 control.

654

Figure 5 HPLC-ESI-TOF-MS analysis of EAEP. (A) Total ion chromatogram (TIC) of 656 blank solution, (B) EAEP sample, and (C) standard compounds [apigenin (Cmpd 1, 24.7 657 min) and galangin (Cmpd 2, 32.9 min)] by negative mode HPLC-ESI-TOF-MS. 
658 Figure 6 Concentration and putative structure of the compounds in EAEP. (A) 659 Concentrations of apigenin and galangin in EAEP measured by HPLC-ESI-TOF-MS. (B) 660 The chemical structure of apigenin and galangin.

661

662 Figure $7{ }^{1} \mathrm{H}-N M R$ spectra of ethyl acetate and EAEP. (A) ${ }^{1} \mathrm{H}-\mathrm{NMR}$ spectra $(400 \mathrm{MHz})$ 663 of ethyl acetate in DMSO- $\mathrm{d}_{6}$. Three sets of protons are responsible for the three signals 664 in the ${ }^{1} \mathrm{H}-\mathrm{NMR}$ spectra of ethyl acetate. The signals at approximately $\delta 1.98,4.02$, and 6651.70 ppm correspond to the $\mathrm{H}_{\mathrm{a}}, \mathrm{H}_{\mathrm{b}}$, and $\mathrm{H}_{\mathrm{c}}$ hydrogens, respectively. (B) The ${ }^{1} \mathrm{H}-\mathrm{NMR}$ 666 spectra $(400 \mathrm{MHz})$ of EAEP in DMSO- $\mathrm{d}_{6}$ did not exhibit signals identifying ethyl acetate. 667 
Figure 1

Cytotoxic evaluation of EAEP on HNSCC cells measured by MTT assay.

The EAEP at various concentrations were used to treat (A) HN30, (B) HN31, (C) HN4, and (D) HN12 cells for $72 \mathrm{~h}$. Bars represent means \pm SEM of three independent experiments $(n=3) . * P$ $<0.05$ compared with the control.

A

HN30

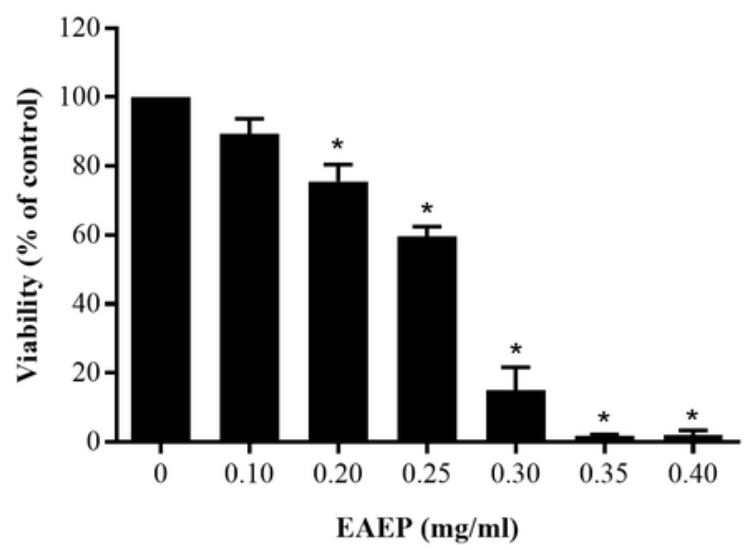

C

HN4

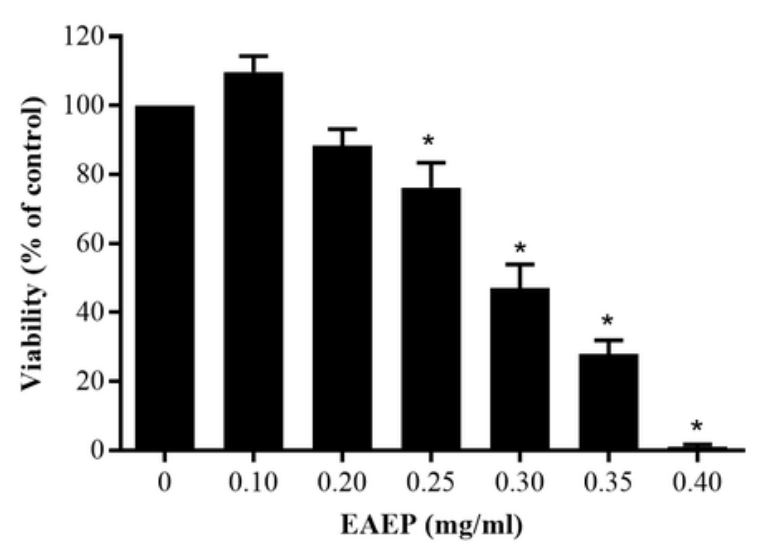

B

HN31

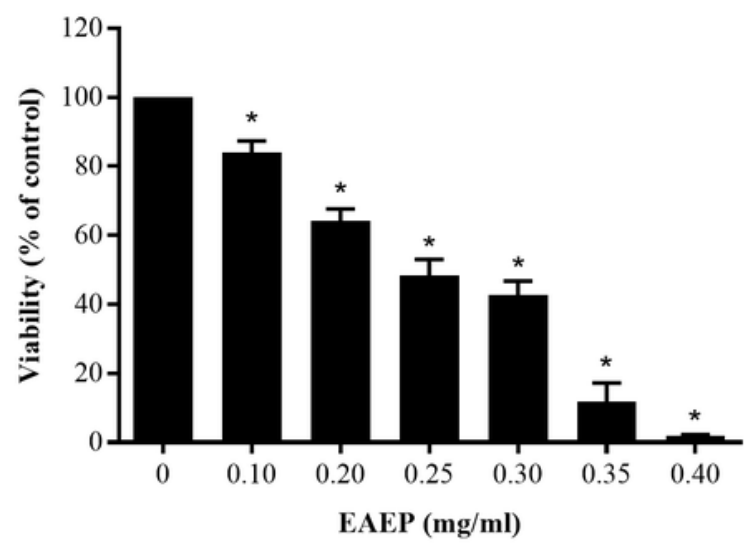

D

HN12

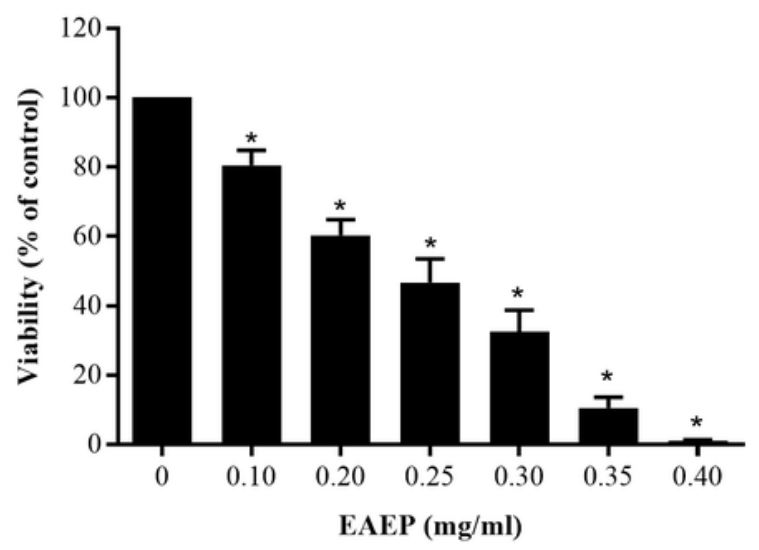


Figure 2

Effect of EAEP on HNSCC cells, after treatment for $24 \mathrm{~h}$, evaluated by flow cytometry.

(A) Dot plots of apoptosis assay with Annexin V-FITC (X-axis)/ 7-AAD-PE (Y-axis). (B)

Percentage of apoptotic HN30, HN31, HN4, and HN12 cells treated with $0.2,0.2,0.3$, and 0.2

$\mathrm{mg} / \mathrm{ml}$ EAEP, respectively for $24 \mathrm{~h}$. Bars represent means \pm SEM of three independent experiments $(n=3) . * P<0.05$ compared with the control. 
A

HN30
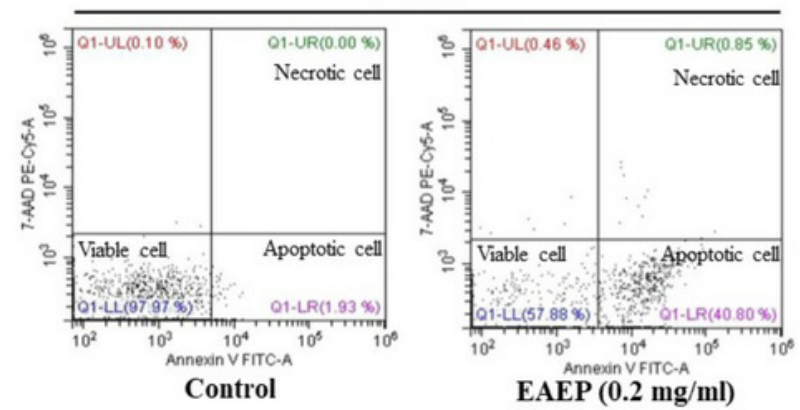

HN4
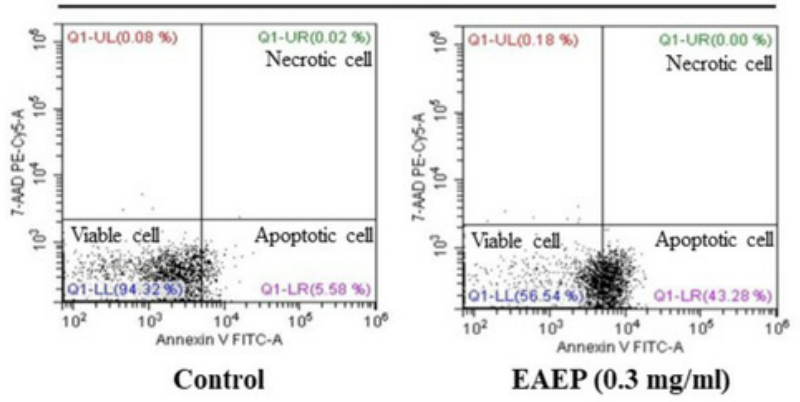

HN31
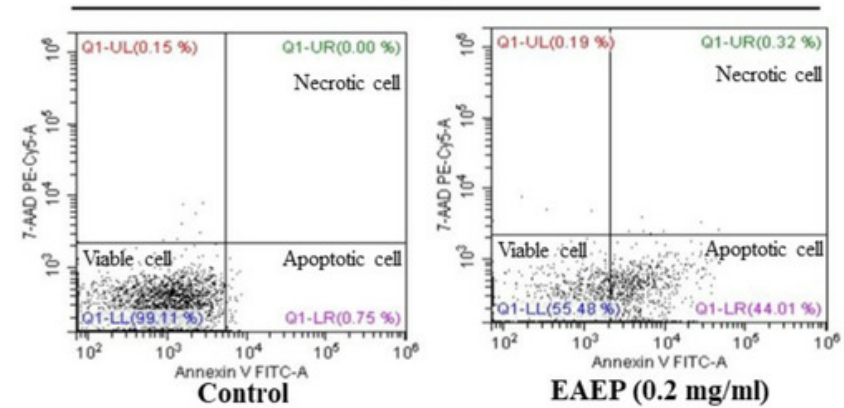

HN12
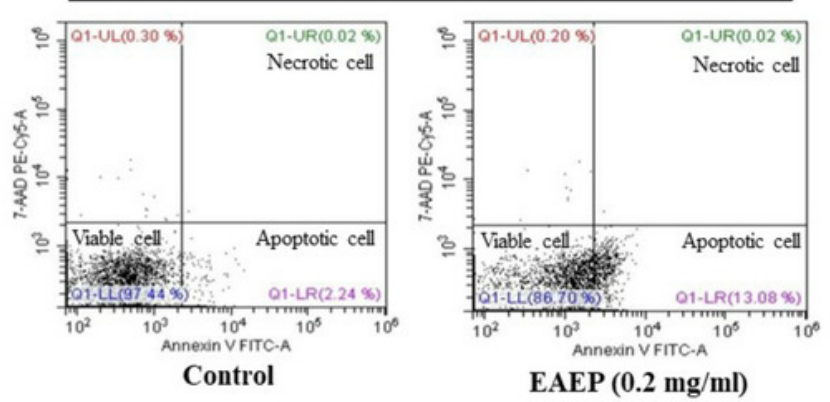

B

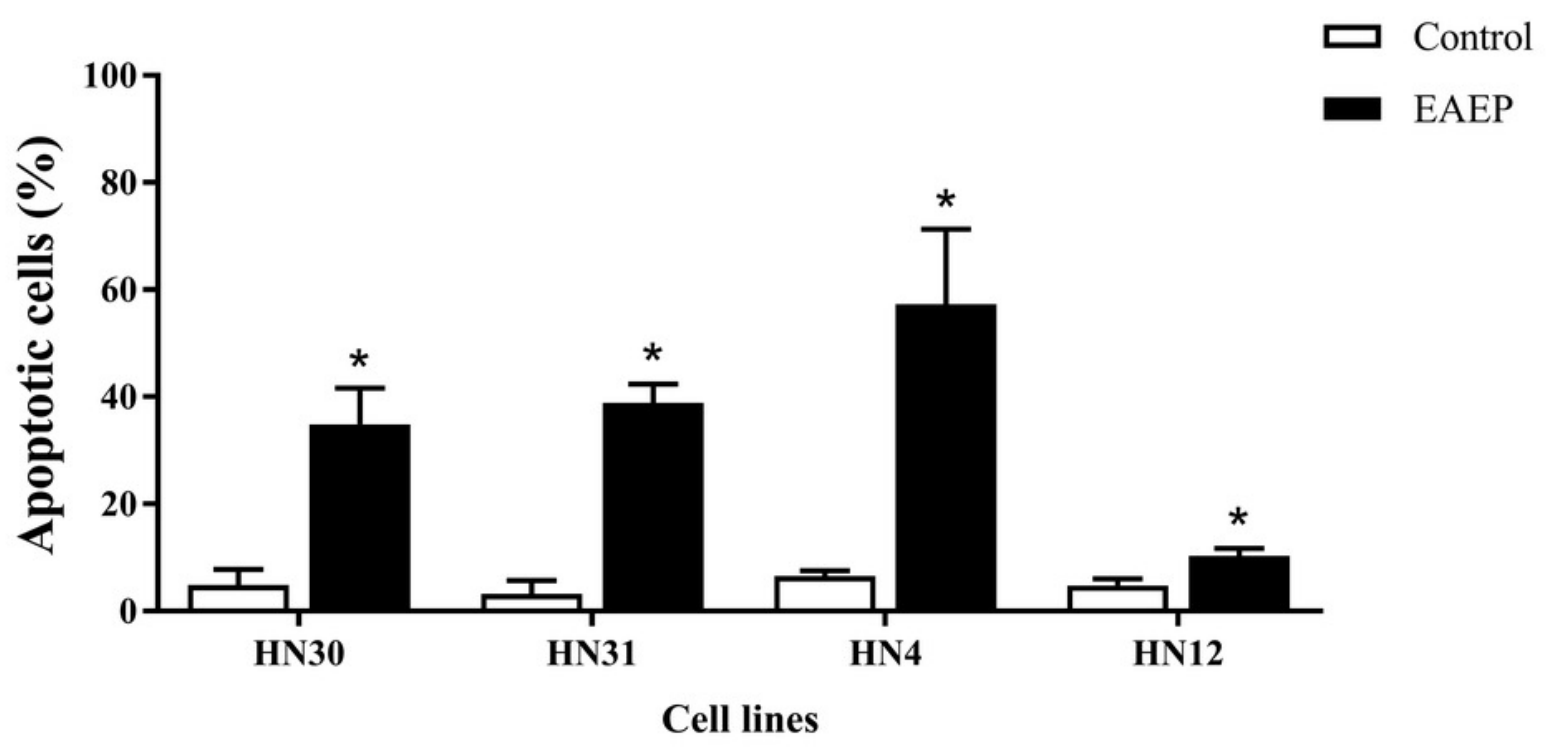




\section{Figure 3}

EAEP decreased HNSCC cell invasion.

A non-cytotoxic dose of EAEP was used to treat HN30, HN31, HN4, and HN12 cells. (A) Representative images of cells that invaded onto the underside of polycarbonate filters coated with Matrigel membrane from Boyden chemoinvasion assays at $400 \times$ magnification using a light microscope. (B) The number of cells of each field was counted using a microscope at $400 \times$ magnification. Values are the mean \pm SEM of three independent experiments $(n=3)$ of. $* P<0.05$ compared with the control. 


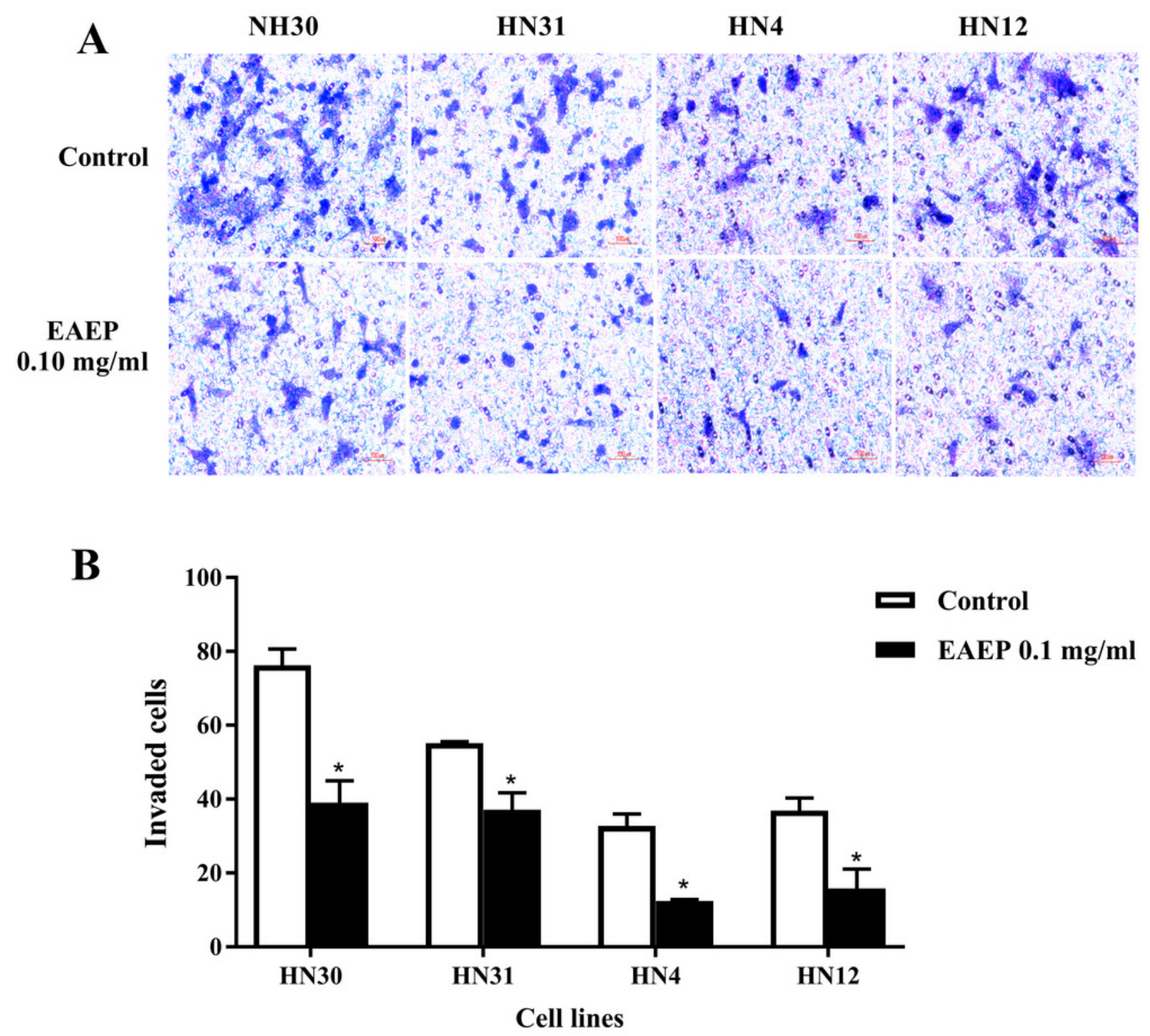


Figure 4

EAEP reduced MMP activities.

$\operatorname{EAEP}(0.1 \mathrm{mg} / \mathrm{ml})$ was used to treat the cancer cells for $48 \mathrm{~h}$ and MMP activity in the conditioned media of (A) HN30 and HN31, and (B) HN4 and HN12 cells were detected using zymography. GeneTools software was used to quantify gelatinolytic bands of (C) MMP-2 and (D) MMP-9 activity. Bars represent means \pm SEM of three independent experiments $(n=3) . * P$ $<0.05$ compared with the control.
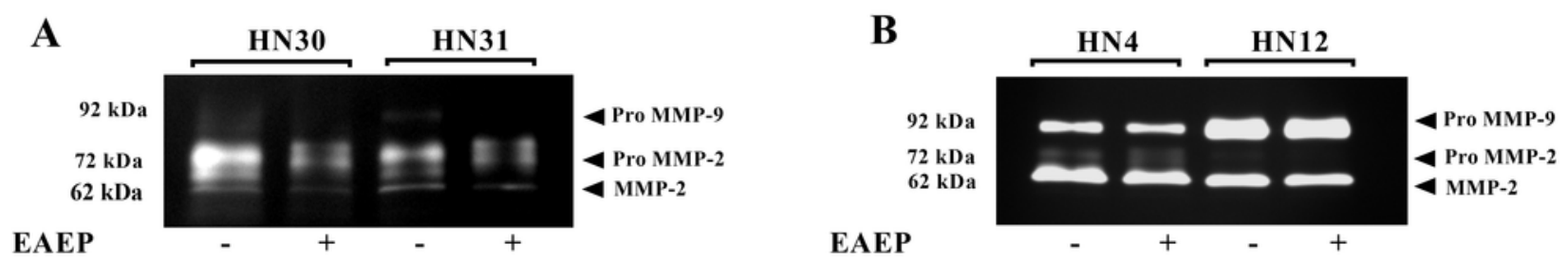

C

MMP-2

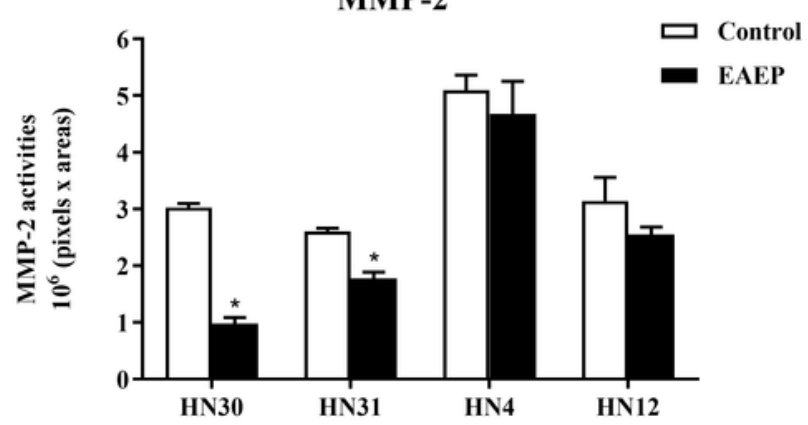

D

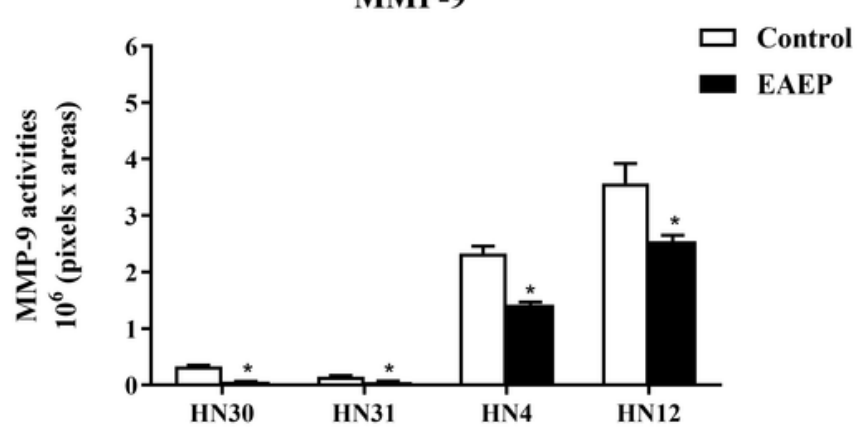


Figure 5

HPLC-ESI-TOF-MS analysis of EAEP.

(A) Total ion chromatogram (TIC) of blank solution, (B) EAEP sample, and (C) standard compounds [apigenin ( $\mathrm{Cmpd} \mathrm{1,} 24.7 \mathrm{~min}$ ) and galangin ( $\mathrm{Cmpd} \mathrm{2,} 32.9 \mathrm{~min}$ )] by negative mode HPLC-ESI-TOF-MS. 


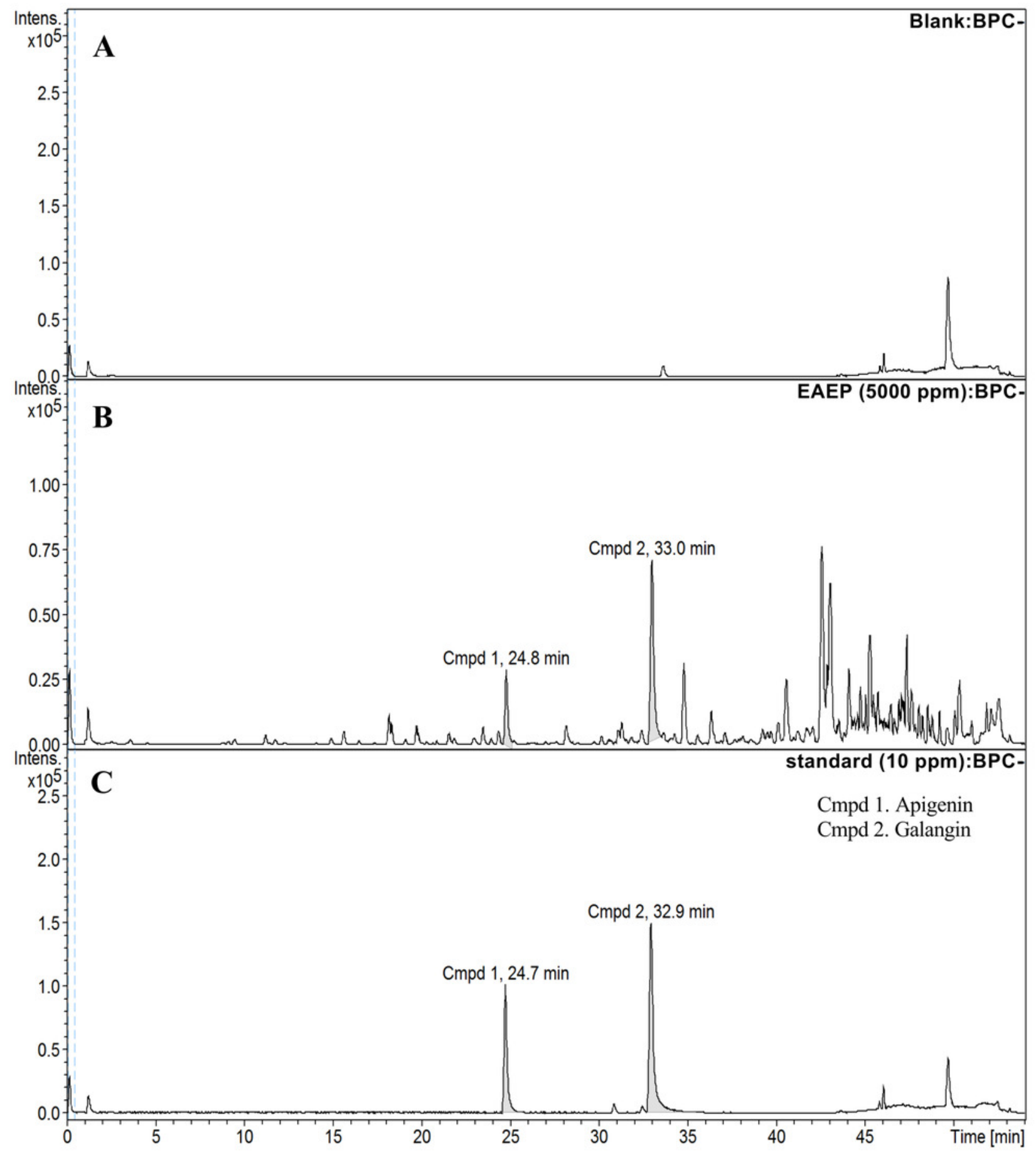


Figure 6

Concentration and putative structure of compounds in EAEP.

(A) Concentrations of apigenin and galangin in EAEP measured by HPLC-ESI-TOF-MS. (B) The chemical structure of apigenin and galangin.

A

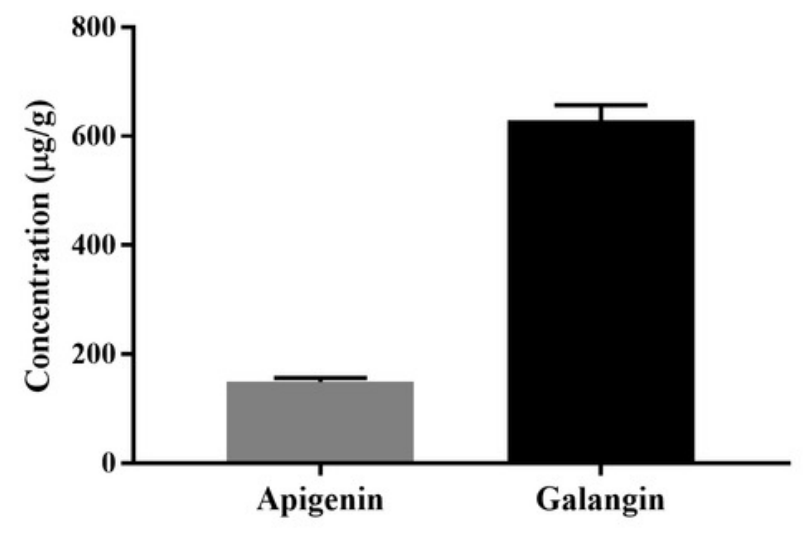

B<smiles>O=c1cc(-c2ccc(O)cc2)oc2cc(O)cc(O)c12</smiles>

Apigenin<smiles>O=c1cc(-c2ccccc2)oc2cc(O)cc(O)c12</smiles>

Galangin 
Figure 7

NMR spectrum of ethyl acetate

(A) ${ }^{1} \mathrm{H}-\mathrm{NMR}$ spectra $(400 \mathrm{MHz})$ of ethyl acetate in DMSO- $\mathrm{d}_{6}$. Three sets of protons are responsible for the three signals in the ${ }^{1} \mathrm{H}-\mathrm{NMR}$ spectra of ethyl acetate. The signals at approximately $\delta 1.98,4.02$, and 1.70 ppm correspond to the $H_{a}, H_{b}$, and $H_{c}$ hydrogens,

respectively. (B) The ${ }^{1} \mathrm{H}-\mathrm{NMR}$ spectra $\left(400 \mathrm{MHz}\right.$ ) of EAEP in DMSO- $\mathrm{d}_{6}$ did not exhibit signals identifying ethyl acetate.

A

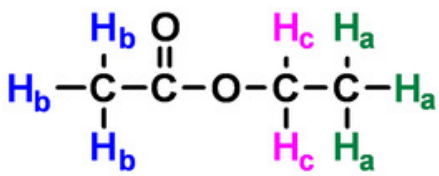

Ethyl acetate

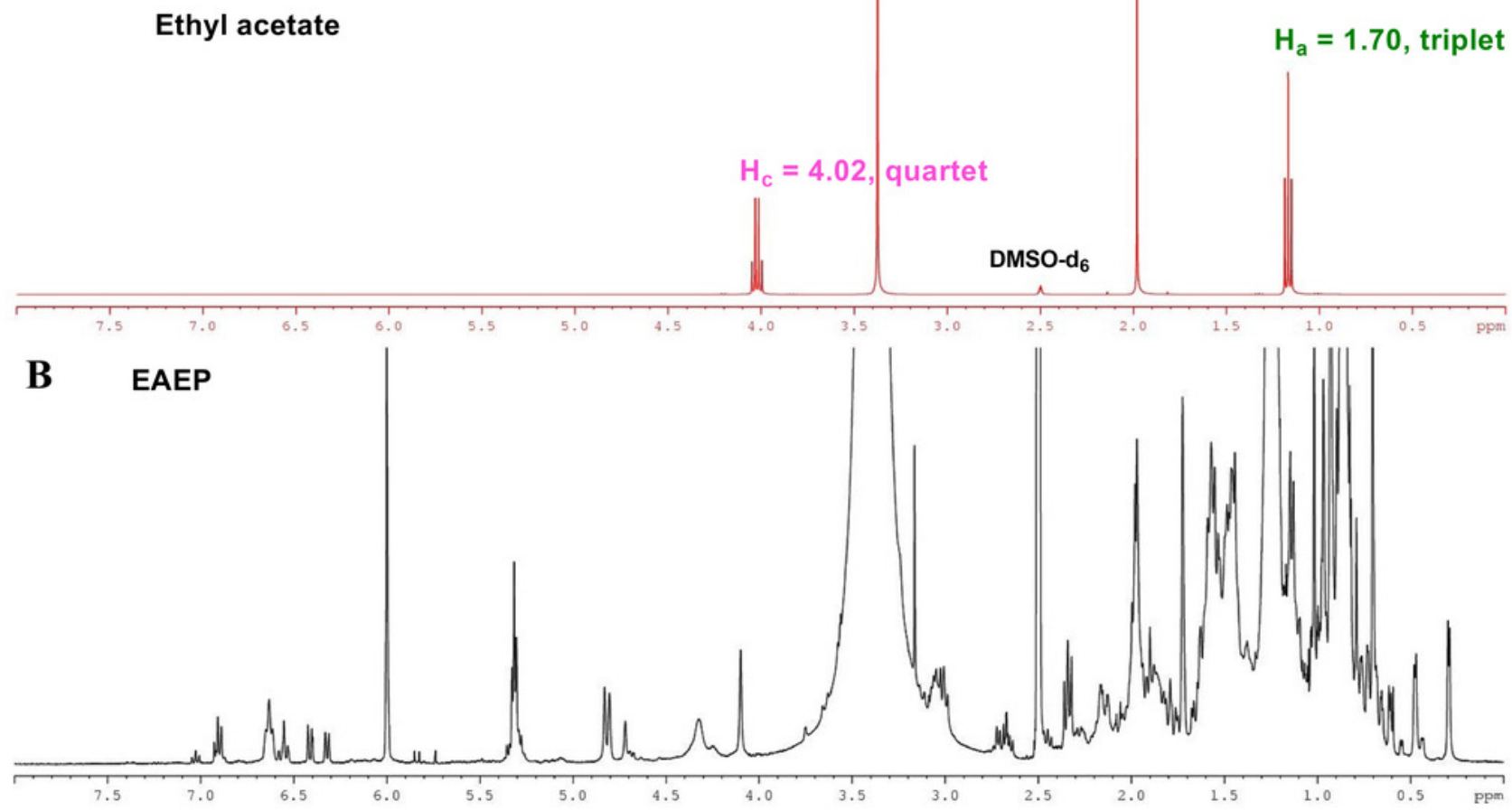




\section{Table $\mathbf{1}$ (on next page)}

Retention time, calculated and detected masses, calculated formula, concentration and putative identification of the two compounds in EAEP analyzed by HPLC-ESI-TOF-MS. 
1 Table 1:

2 Retention time, calculated and detected masses, calculated formula, concentration and

3 putative identification of the two compounds in EAEP analyzed by HPLC-ESI-TOF-MS

\begin{tabular}{lcccccc}
\hline Peak & $\begin{array}{c}\text { Retention time } \\
(\mathrm{min})\end{array}$ & $\begin{array}{c}\text { Calculated } \\
\text { mass }[\mathrm{M}-\mathrm{H}]^{-} \\
(\mathrm{m} / \mathrm{z})\end{array}$ & $\begin{array}{c}\text { Detected } \\
\text { mass }[\mathrm{M}-\mathrm{H}]^{-} \\
(\mathrm{m} / \mathrm{z})\end{array}$ & $\begin{array}{c}\text { Calculated } \\
\text { formula }[\mathrm{M}-\mathrm{H}]^{-}\end{array}$ & $\begin{array}{c}\text { Concentration } \\
(\mu \mathrm{g} / \mathrm{g})\end{array}$ & $\begin{array}{c}\text { Putative } \\
\text { Identification }\end{array}$ \\
\hline Cmpd 1 & 24.8 & 269.0455 & 269.0465 & $\mathrm{C}_{15} \mathrm{H}_{9} \mathrm{O}_{5}$ & 149.0 & Apigenin \\
Cmpd 2 & 33.0 & 269.0455 & 269.0471 & $\mathrm{C}_{15} \mathrm{H}_{9} \mathrm{O}_{5}$ & 628.6 & Galangin \\
\hline
\end{tabular}

4

5

6

7

8

9

10

11

12

13

14 